\title{
Ten1p promotes the telomeric DNA-binding activity of Cdc13p: implication for its function in telomere length regulation
}

\author{
Wei Qian ${ }^{1,2}$, Jianyong Wang ${ }^{1}, \mathrm{Na}-\mathrm{Na} \mathrm{Jin}^{2}$, Xiao-Hong Fu ${ }^{1}$, Yi-Chien Lin ${ }^{3}$, Jing-Jer Lin ${ }^{3}$, Jin-Qiu Zhou ${ }^{1}$ \\ ${ }^{I}$ The State Key Laboratory of Molecular Biology, Institute of Biochemistry and Cell Biology, Shanghai Institutes for Biological \\ Sciences, Chinese Academy of Sciences, The Graduate School of Chinese Academy of Sciences, Shanghai 200031, China; ${ }^{2}$ Depart- \\ ment of Biochemistry, School of Medicine, Nantong University, Nantong, Jiangsu 226001, China, ${ }^{3}$ Institute for Biopharmaceutical \\ Science, National Yang-Ming University, Shih-Pai, 112, Taipei, Taiwan
}

In Saccharomyces cerevisiae, the essential gene CDC13 encodes a telomeric single-stranded DNA-binding protein that interacts with Stn1p and Ten1p genetically and physically, and is required for telomere end protection and telomere length control. The molecular mechanism by which Ten1 participates in telomere length regulation and chromosome end protection remains elusive. In this work, we observed a weak interaction of Cdc13p and Ten1p in a gelfiltration analysis using purified recombinant Cdc13p and Ten1p. Ten1p itself exhibits a weak DNA-binding activity, but enhances the telomeric TG $_{1-3}$ DNA-binding ability of Cdc13p. Cdc13p is co-immunoprecipitated with Ten1p. In the mutant ten 1-55 or ten1-66 cells, the impaired interaction between Ten1p and Cdc13p results in much longer telomeres, as well as a decreased association of Cdc13p with telomeric DNA. Consistently, the Ten1-55 and Ten1-66 mutant proteins fail to stimulate the telomeric DNA-binding activity of Cdc13p in vitro. These results suggest that Ten1p enhances the telomeric DNA-binding activity of Cdc13p to negatively regulate telomere length.

Keywords: telomere, Cdc13, Ten1, Stn1

Cell Research (2009) 19:849-863. doi: 10.1038/cr.2009.67; published online 16 June 2009

\section{Introduction}

Telomeres are nucleoprotein structures that protect the ends of linear chromosomes from nucleolytic degradation and end-to-end fusion [1, 2]. They are usually elongated by the specialized reverse transcriptase, telomerase, which is composed of a catalytic subunit and an RNA template [3]. Besides telomerase, many other proteins and their complexes are involved in telomere maintenance [4]. In Saccharomyces cerevisiae, Est1p, Est2p, Est $3 p$, Tlc1 and Cdc13p are necessary for the in vivo telomerase activity [4], although only Est $2 p$ and Tlc1, the catalytic and RNA subunits of telomerase, respectively, are required for the in vitro telomerase activity [5-7].

Correspondence: Jin-Qiu Zhou

Tel: 86-21-54921076; E-mail: jqzhou@sibs.ac.cn

Received 6 October 2008; revised 11 January 2009; accepted 15 February 2009; published online 16 June 2009
The $3^{\prime}$ end of telomeric DNA usually exists as a single-stranded G-rich overhang (also called G-tail) [8]. In $S$. cerevisiae, the $3^{\prime}$ overhang of telomere is bound and protected by an RPA-like trimeric protein complex of $\mathrm{Cd}$ c13p/Stn1p/Ten1p [9]. Cdc13p, a 105-kDa protein, binds single-stranded telomeric $\mathrm{TG}_{1-3}$ DNA specifically both in vitro $[10,11]$ and in vivo $[12,13]$. The DNA-binding domain of Cdc13p resides in a 187-amino acid fragment from the amino acid 500 to 686 [14-18]. The binding of Cdc13p to telomere ends protects telomeres from nuclease attack [10]. In addition, Cdc13p has been shown to interact with Est1p to mediate telomerase recruitment [19, 20].

Stn1p was identified by a genetic screening for multicopy suppressors of the $c d c 13-1$ mutation [21]. Like cdc13-1 mutant [22], the stn 1-13 cells accumulate singlestranded subtelomeric DNA at the restrictive temperature of $37{ }^{\circ} \mathrm{C}$ [21]. Mutation of STN1 increases telomere length $[21,23]$. Stn $1 p$ interacts with $\mathrm{Cdc} 13 p$ in the yeast two-hybrid analysis [16, 21, 23-26]. Recently, studies on 
the separation-of-function alleles of STN1 revealed that the N-terminus of Stn1p interacts with Ten $1 \mathrm{p}$ and carries out its essential capping function, while the $\mathrm{C}$-terminus of Stn $1 p$ binds both Cdc13p and Pol12p to limit continuous telomerase action for telomere length regulation [24, 26].

Ten $1 \mathrm{p}$, a conserved single-stranded telomeric DNAbinding protein, interacts with both Stn $1 p$ and Cdc13p $[23,27]$. Genetic studies showed that co-overexpression of $\operatorname{Stn} 1 \mathrm{p}$ and Ten $1 \mathrm{p}$ rescues the telomere defects of cdc13-1 mutant [23, 25]. Some mutants of TEN1 exhibit longer telomere and some temperature-sensitive mutants of TEN1 arrest at $\mathrm{G}_{2} / \mathrm{M}$ via activation of the Rad9-dependent DNA damage checkpoint, and they accumulate single-stranded DNA in telomeric regions [23]. Stn113 mutant protein fails to interact with Ten $1 \mathrm{p}$, which is responsible for the long telomere phenotype of $\sin 1-13$ mutant cells [23]. By a yeast two-hybrid assay, Ten $1 \mathrm{p}$ was shown to interact with Cdc13p [23]. These lines of evidence indicate that $\mathrm{Cdc} 13 \mathrm{p} / \mathrm{Stn} 1 \mathrm{p} / \mathrm{Ten} 1 \mathrm{p}$ complex plays an essential role in telomere protection and length regulation [23]. However, how Ten $1 p$ contributes to telomere replication remains elusive. In this work, we have used both biochemical and genetic approaches to examine the interaction between Ten $1 p$ and Cdc13p. Our results indicate that Ten $1 \mathrm{p}$ interacts with $\mathrm{Cdc} 13 \mathrm{p}$ to promote its $\mathrm{TG}_{1-3}$ DNA-binding activity.

\section{Results}

Ten1p interacts with Cdc13p or Stn1p when they are cooverexpressed in insect cells

Cdc13p, Stn1 $p$ and Ten1 $p$ were suggested to genetically and/or physically interact with each other to form a complex $[9,16,21,23,25]$. However, the direct interaction between Cdc13p and Ten1p has not been elucidated. Since we have obtained the recombinant baculovirus expressing Cdc13p [18], we generated recombinant baculoviruses for His-tagged Stn $1 p$ and Ten $1 p$, and co-overexpressed these three proteins in the insect cell line of Sf9. The infection or co-infection of insect cells resulted in the overexpression or co-overexpression of Ten1p, Histagged Stn1p and/or His-tagged Cdc13p, as detected by western blot using anti-Ten1p (Figure 1A, lower panel) or anti-Cdc13p, anti-Stn1p antibodies (Figure 1A, upper panel). Although the antibodies against Ten1p, Stn $1 p$ and/or Cdc13p cross-reacted with some proteins (indicated by asterisks in Figure 1A) in insect cells, the distinct bands of Ten1p, Stn1p and/or Cdc13p, which were not detected in the crude extract of insect cells, were observed (indicated at the right of Figure 1A). Similar levels of Ten $1 p$ expression were seen in the cell lysates with or without co-expressed Cdc13p (Figure 1A, lane $4,7,8$ ) and/or Stn1p (Figure 1A, lane 4, 6, 8). To detect the physical interaction between Cdc13p and Ten1p, or between Stn1p and Ten1p, we used Ni-NTA beads to pull down His-tagged Cdc13p and/or His-tagged Stn1p, and examined the presence of non-tagged Ten $1 p$ when Ten $1 p$ was co-overexpressed with His-tagged Cdc13p and/or His-tagged Stn1p (Figure 1B, lane 2, 3 and 4). Ten $1 \mathrm{p}$ was co-purified with Cdc13p (lane 2 and 4) and/or Stn1p (lane 3 and 4). These results suggest that Ten $1 p$ interacts with both Cdc13p and Stn1p, consistent with the previous report [23].

\section{Purification of recombinant Ten1p from Escherichia coli}

To validate the interaction between Ten $1 \mathrm{p}$ and $\mathrm{Cd}$ c13p, we tried to further purify the Cdc13p/Ten1p complex from insect cells. However, the Cdc13p/Ten $1 p$ complex was not stable, and disassembled in the following Q sepharose ion exchange column (data not shown). We then turned to purify recombinant Ten $1 \mathrm{p}$ from E. coli, and anticipated that we should be able to analyze their interaction with purified recombinant proteins. The Histagged Ten $1 \mathrm{p}$ was overexpressed in E. coli and purified to near homogeneity with affinity chromatography and ion exchange chromatography on Ni-NTA and heparin agarose columns, respectively (Figure 1C, and see Materials and Methods). The purified recombinant Ten $1 \mathrm{p}$ (Figure 1C, lane 4) was concentrated to $400 \mathrm{ng} / \mu \mathrm{l}$ for further characterization.

Previous study has shown that Ten $1 p$ could bind telomeric DNA by itself at micro-molar level [9]. We also examined the DNA-binding activity of recombinant Ten $1 p$ with electrophoretic mobility shift assay (EMSA) using a single-stranded telomeric $\mathrm{TG}_{1-3}$ DNA probe. In contrast to Cdc13p, which could bind telomeric singlestranded $\mathrm{TG}_{1-3}$ DNA at nano-molar level (Figure 3A) [18], Ten $1 \mathrm{p}$ seemed not to bind telomeric single-stranded $\mathrm{TG}_{1-3}$ DNA until its concentration reached $6.5 \mu \mathrm{M}$ (Figure 1D).

\section{Purified recombinant $C d c 13 p$ and Ten 1p interact with each other in vitro}

In order to examine a direct interaction between Ten $1 \mathrm{p}$ and $\mathrm{Cdc} 13 \mathrm{p}$, we purified His-tagged recombinant $\mathrm{Cd}$ c13p from the insect cells (Figure 2A) [18]. The molecular mass of purified recombinant $\mathrm{Cdc} 13 \mathrm{p}$ was estimated in an analytical Superdex 200 (10/300) (Amasham pharmacia) gel-filtration column, which was calibrated with protein standards including Ferrin $(440 \mathrm{kDa})$, Albumin (66 kDa), Ovalbumin (43 kDa) and Ribonuclease A (13.7 $\mathrm{kDa}$ (Figure 2B). It appeared that the elution of Cdc13p peaked at fraction 19 (Figure 2B, upper panel), which 
A

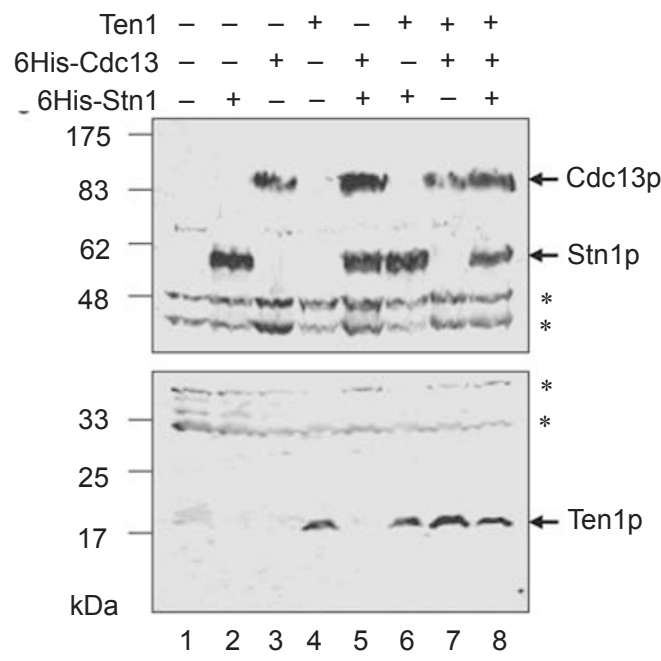

C

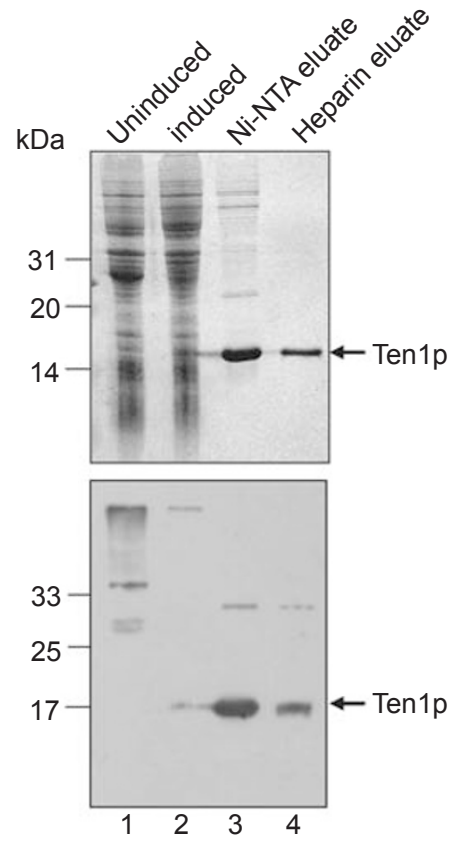

B
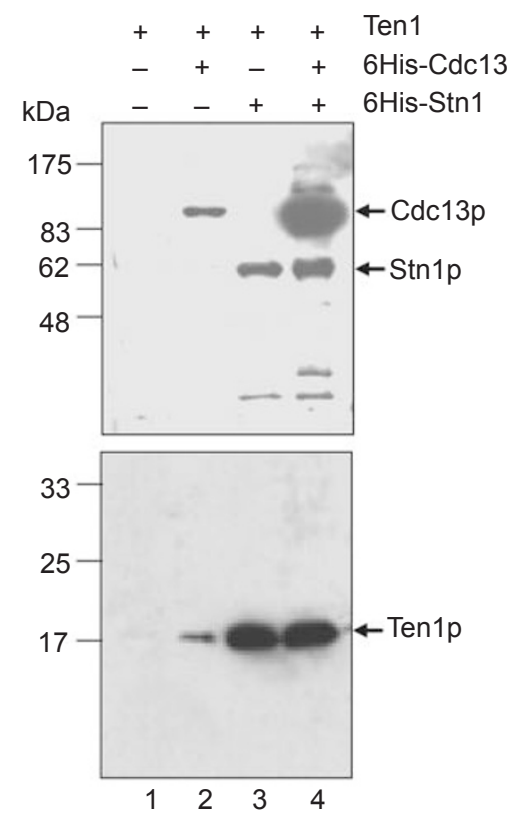

D

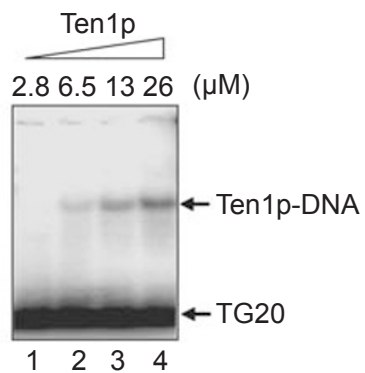

Figure 1 Physical interaction between Cdc13p and Ten1p in insect cells. (A) Co-overexpression of Cdc13p, Stn1p and Ten1p in Sf9 cells. Sf9 cells were infected or co-infected with Cdc13, Stn1 and/or Ten1 recombinant baculoviruses. The expression of three proteins was detected by western blot with both anti-Cdc13p and anti-Stn $1 p$ antibodies (upper panel) or anti-Ten1p antibodies (lower panel). The non-specific cross-reaction bands are indicated with asterisks. The protein standards are indicated on the left of the Figures. (B) Co-pull down Ten1p with His-tagged Stn1p or His-tagged Cdc13p. Sf9 cells were coinfected with Cdc13/Ten1 viruses, Stn1/Ten1 viruses or Cdc13/Stn1/Ten1 viruses, and $\operatorname{Stn} 1 p$ and Cdc13p were pulled down with Ni-NTA affinity beads. The proteins retained in the beads were examined by western blot with anti-Cdc13p and anti-St$\mathrm{n} 1 \mathrm{p}$ antibodies (upper panel), or anti-Ten1p antibodies (lower panel). (C) Purification of His-tagged Ten1p. His-tagged Ten1p was overexpressed in E. coli, and purified through chromatography on Ni-NTA and Heparin agarose as described in Materials and Methods. The recombinant Ten $1 \mathrm{p}$ was examined by Coomassie blue-stained SDS-PAGE (upper panel) and western blot with anti-Ten1p antibodies (lower panel). (D) Binding of Ten1p to single-stranded telomeric TG20 DNA. The purified Ten1p at different concentrations (indicated on top of the gel) was incubated with $2.4 \mathrm{nM}$ of ${ }^{32} \mathrm{P}$ labeled TG20, and its DNA-binding activity was examined by electrophoretic mobility shift assay (EMSA) as described in Materials and methods. 
A

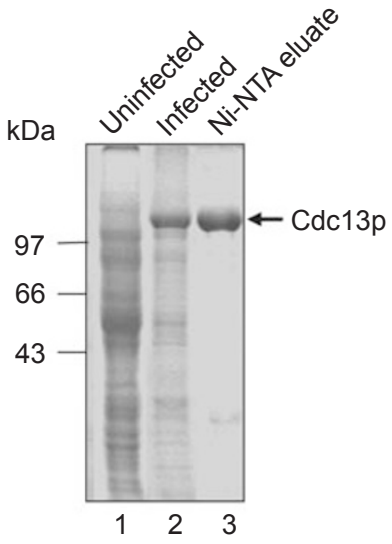

C

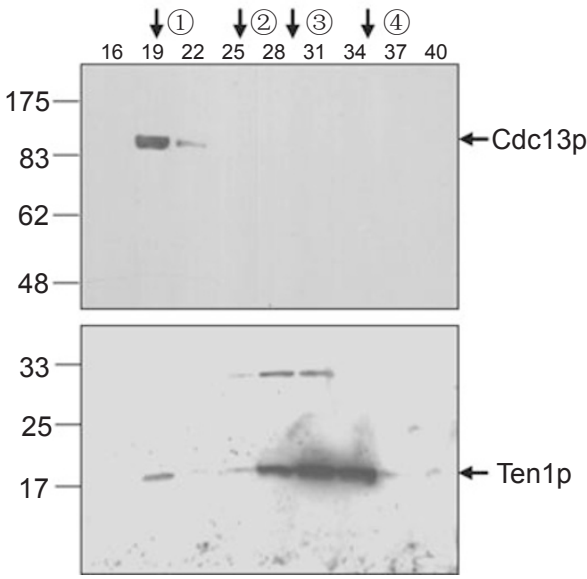

B

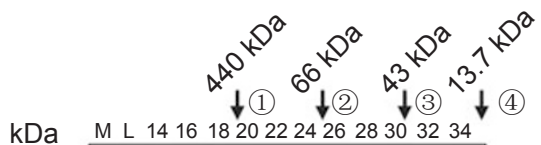

$\mathrm{kD}$ M L 1416182022242628303234
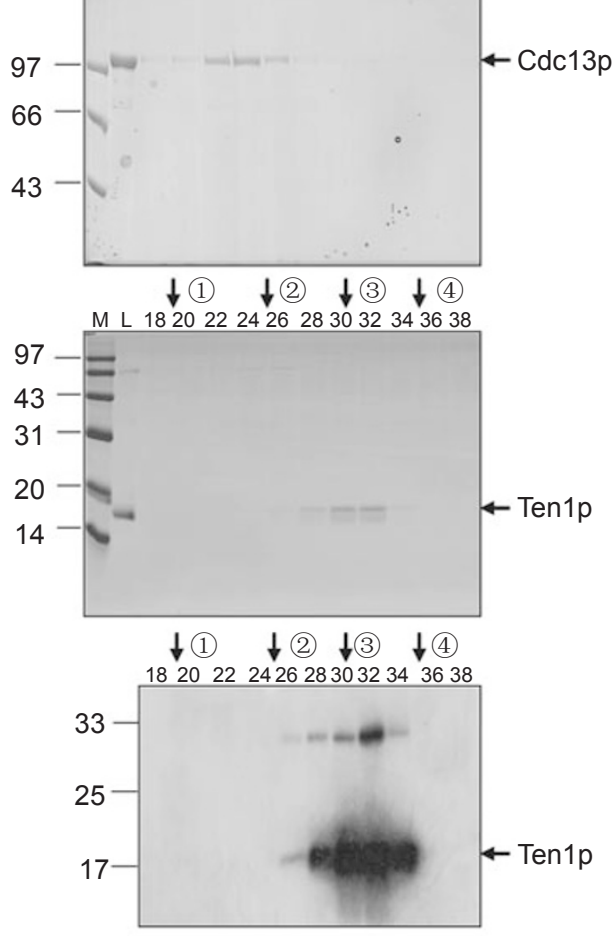

Figure 2 Co-fractionation of purified recombinant Cdc13p and Ten1p. (A) Purification of recombinant Cdc13p in insect cells (Sf9). His-tagged Cdc13p was overexpressed and purified on Ni-NTA affinity chromatography as described previously [18], and examined by Coomassie blue-stained SDS-PAGE. (B) Gel-filtration analysis of purified recombinant Cdc13p and Ten1p (see Materials and Methods). A total of $204 \mu \mathrm{g}$ of the purified recombinant Cdc13p (upper panel) or $36 \mu \mathrm{g}$ of the purified recombinant Ten1p (middle and lower panels) was loaded onto a Superdex 200 size exclusion column, and the elution of the Cdc13p or Ten1 $p$ was examined by Coomassie blue-stained SDS-PAGE (upper and middle panels) and western blot with antiTen1p antibodies (lower panel). (C) Co-fractionation of Ten1p with Cdc13p in a gel-filtration analysis. A total of $204 \mu \mathrm{g}$ of the recombinant Cdc13p and $36 \mu \mathrm{g}$ of the recombinant Ten1p (molecular ratio of Cdc13p:Ten1p is 1:1) were incubated and subjected to the same Superdex 200 column, and elution of both Cdc13p and Ten $1 p$ were examined by western blot with antiCdc13p (upper panel) and anti-Ten1p (lower panel) antibodies, respectively. The calibration of the Superdex 200 gel-filtration column was performed with protein standards including Ferrin (440 kDa (1)), Albumin (66 kDa (2)), Ovalbumin (43 kDa (3)) and Ribonuclease $\mathrm{A}(13.7 \mathrm{kDa}$ (4)), which are indicated on the tops of the panels. The number on the top of each panel indicates the elution fractions.

corresponds to a molecular weight of $\sim 400 \mathrm{kDa}$, suggesting that $\mathrm{Cdc} 13 \mathrm{p}$ might form an oligomer, e.g., tetramer. We used either high salt (e.g., $1 \mathrm{M} \mathrm{NaCl}$ ) or $1 \%$ Triton $\mathrm{X}-100$ to treat $\mathrm{Cdc} 13 \mathrm{p}$, and these treatments could not change the behavior of Cdc13p in the gel-filtration assay. The purified recombinant Ten $1 p$ was also subjected to the same gel-filtration column, and the results showed that Ten1p was mainly eluted at fractions 30-32 (Figure
2B, middle and lower panels), indicating that Ten1p exists as a monomer in solution.

To analyze the interaction between Ten $1 \mathrm{p}$ and $\mathrm{Cd}$ c13p, $36 \mu \mathrm{g}$ of purified recombinant Ten $1 \mathrm{p}$ (Figure 1C) and $204 \mu \mathrm{g}$ of purified recombinant Cdc13p (Figure 2A) were incubated on ice for $2 \mathrm{~h}$, and loaded on the same analytical Superdex 200 gel-filtration column, and the column was developed as was done with $\mathrm{Cdc} 13 \mathrm{p}$ or 
A

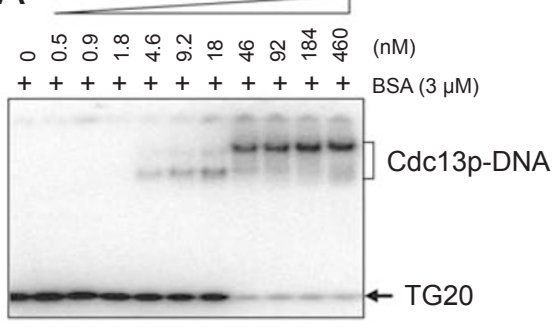

$+++++++++$ Ten1p $(2.8 \mu \mathrm{M})$

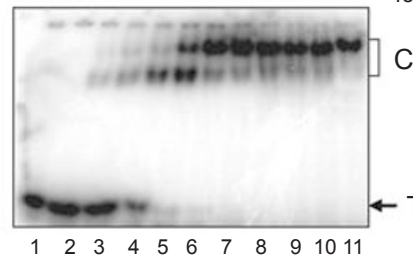

Cdc13p-DNA TG20

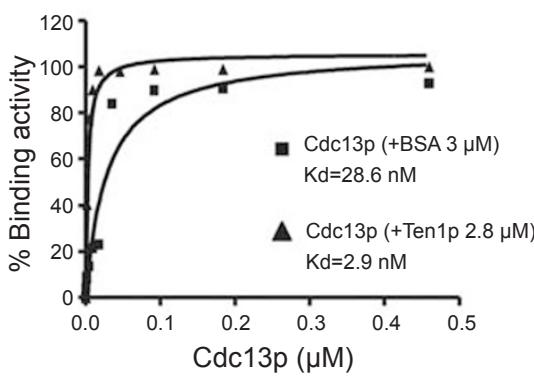

B

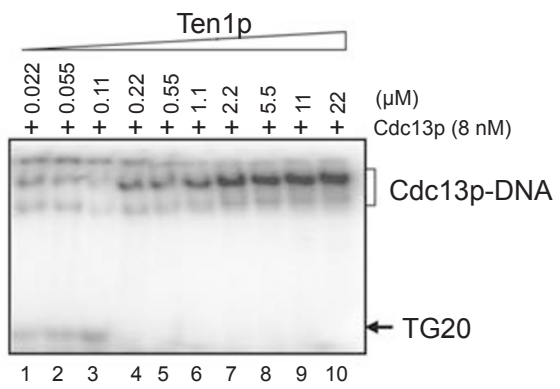

C

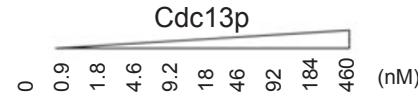

$++++++++++\mathrm{BSA}(3 \mu \mathrm{M})$

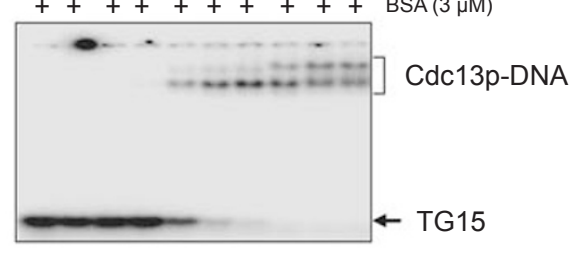

$++++++++++\quad$ Ten $1 \mathrm{p}(2.8 \mu \mathrm{M})$

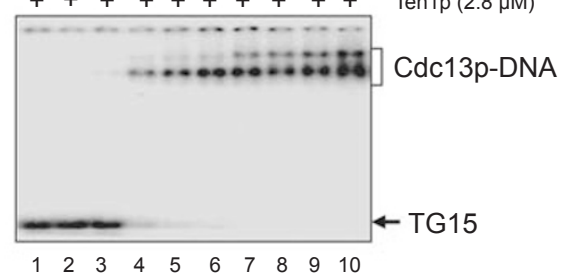

$\begin{array}{lllllllllll}1 & 2 & 3 & 4 & 5 & 6 & 7 & 8 & 9 & 10\end{array}$
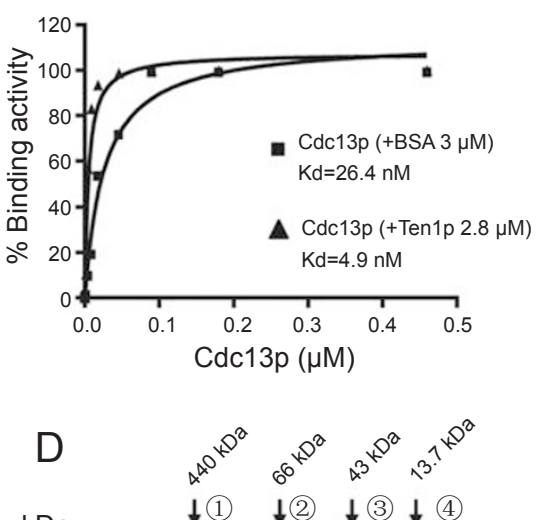

kDa L 141618 (1) $\downarrow$ (2) $\downarrow$ (3) $\downarrow$ (4)

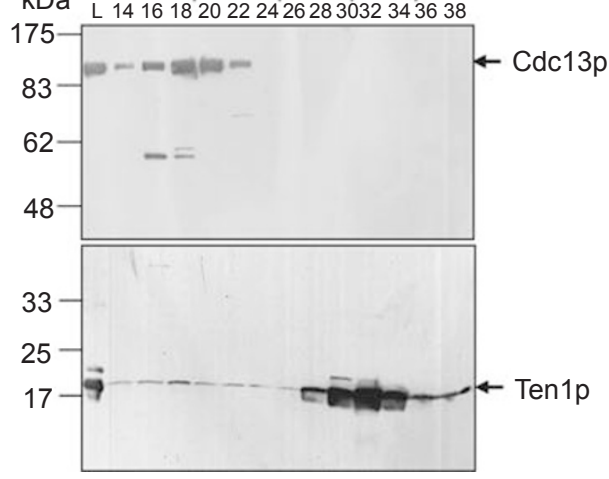

Figure 3 Ten1p stimulates the DNA-binding activity of Cdc13p. (A) and (C) Ten1p promotes the binding activity of Cdc13p to TG20 (A) and TG15 DNA (C). In the upper panel, the purified Cdc13p at different concentrations as indicated on top of the gel was incubated with $2.4 \mathrm{nM}$ of ${ }^{32} \mathrm{P}$-labeled TG20 (A) or TG15 (C) and their binding activity were examined by EMSA as described in Materials and Methods. In the middle panel, $2.4 \mathrm{nM}$ of ${ }^{32} \mathrm{P}$-labeled TG20 (A) or TG15 (C), the purified Ten1p $(2.8 \mu \mathrm{M})$ and $\mathrm{Cdc} 13 p$ at different concentrations (indicated on top of the gel) were incubated, and the protein-DNA complexes were examined by EMSA. In the lower panel, comparison of the TG DNA-binding affinity of Cdc13p with $(\boldsymbol{\Delta})$ or without $(\mathbf{\square})$ Ten1p. The intensity of bands corresponding to free DNA and protein-DNA complex in each lane was quantified using Scion Image software. A nonlinear regression equation (Graph Pad Prism software) was used to plot the upper and middle graphs. The curve for $\operatorname{Cdc13p}(\boldsymbol{\square})$ was deduced from upper panel, and the curve for $\operatorname{Cdc} 13 p$ in the presence of Ten1p ( $\boldsymbol{\Delta})$ was deduced from middle panel. Kds, which represent the equilibrium binding constants, were automatically generated in the software program. (B) A total of $8 \mathrm{nM}$ of Cdc13p and different concentration of Ten1p were used. (D) Interaction between Cdc13p and Ten $1 p$ in the presence of TG15 DNA. In total, $100 \mu \mathrm{g}$ of the purified recombinant Cdc13p, $252 \mu \mathrm{g}$ of the purified Ten1p and $10 \mu \mathrm{g}$ of TG15 DNA (molecular ratio of Cdc13p:Ten1p:TG15 is 1:14:2) were incubated and subjected to Superdex 200 column. The elution fractions were examined by western blot with anti-Cdc13p antibodies (upper panel) and anti-Ten $1 p$ antibodies (lower panel). 
Ten $1 \mathrm{p}$. In contrast to Ten $1 \mathrm{p}$ alone (Figure 2B, middle and lower panels), an additional small peak of Ten $1 p$ appeared around the fraction 19 (Figure 2C, lower panel) where $\mathrm{Cdc} 13 \mathrm{p}$ was eluted (Figure $2 \mathrm{C}$, upper panel), indicating that Ten $1 p$ was co-eluted with Cdc13p. These data suggest that Ten $1 p$ and Cdc13p interact with each other to form a complex. However, only a small portion of the recombinant Ten $1 p$ formed a complex with Cdc13p (Figure 2C), indicating that the Cdc13p/Ten $1 \mathrm{p}$ complex reconstituted in vitro is not stable.

Ten1p promotes the DNA-binding activity of Cdc13p in vitro

Since Ten $1 \mathrm{p}$ binds telomeric DNA poorly (Figure 1D), and interacts with Cdc13p directly (Figure 2C), it is possible that Ten $1 p-C d c 13 p$ interaction affects the telomeric DNA-binding activity of Cdc13p. To test this possibility, we examined the DNA-binding activity of Cdc13p in the presence of recombinant Ten1p. Strikingly, Ten $1 p$ enhanced the $\mathrm{TG}_{1-3}$ DNA-binding affinity of Cdc13p. In the absence of Ten1p, the Cdc13p-TG20 complex was detected when the Cdc13p concentration was at $4.6 \mathrm{nM}$ (Figure 3A, lane 5). The equilibrium binding constant (Kd) of Cdc13p for TG20 is about $28.6 \mathrm{nM}$ (Figure 3A upper and lower panels). In contrast, in the presence of $2.8 \mu \mathrm{M}$ of Ten $1 \mathrm{p}$, the concentration at which Ten $1 \mathrm{p}$ DNA interaction was not detected, the Cdc13p-DNA complex was observed when Cdc13p was at $0.5 \mathrm{nM}$ (Figure 3A middle panel, lane 2). The $\mathrm{Kd}$ of Cdc13p for TG20 reduced $\sim 10$-fold to $2.9 \mathrm{nM}$ (Figure $3 \mathrm{~A}$ middle and lower panels). A total of $4.6 \mathrm{nM}$ of Cdc13p could completely shift $2.4 \mathrm{nM}$ of TG20 when the Ten1p concentration was at $2.8 \mu \mathrm{M}$ (Figure $3 \mathrm{~A}$ middle panel, lane 5). Consistently, $8 \mathrm{nM}$ of Cdc13p could shift most of the $2.4 \mathrm{nM}$ of TG20 when the Ten $1 \mathrm{p}$ concentration was at $0.22 \mu \mathrm{M}$ (Figure 3B, lane 4). Because Ten $1 \mathrm{p}$ is about 18 $\mathrm{kDa}$, it is hard to tell whether the shifted protein-DNA complex (Figure 3A middle panel) contained Ten $1 \mathrm{p}$ or not. Therefore, it remains possible that Cdc13p-Ten $1 p$ interaction promotes the DNA-binding activity of the protein complex. The stoichiometry of Cdc13p, Ten1p and TG20 oligo DNA was complicated by Cdc13p tetramer formation, weak Cdc13p-Ten $1 p$ interaction and different Cdc13p-TG20 complexes.

To further address whether Ten1p affects the DNAbinding activity of Cdc13p, we used TG15 oligo to examine Cdc13p activity, because 15-mer oligo is an optimal substrate for Cdc13p binding [18], and the binding of Cdc13p to TG15 would leave little space on DNA for Ten $1 p$ binding. When TG15 was substituted for TG20, the $\mathrm{Kd}$ of Cdc13p for TG15 is $4.9 \mathrm{nM}$ in the presence of $2.8 \mu \mathrm{M}$ of Ten $1 \mathrm{p}$ (Figure $3 \mathrm{C}$ middle and lower panels), which is $\sim$ fivefold lower than the Kd of Cdc13p alone for TG15 (Figure 3C upper and lower panels). Interestingly, the pattern of the Cdc13p-TG15 complex (Figure 3C) was different from that of Cdc13p-TG20 (Figure $3 \mathrm{~A}$ ), and the nature of these multiple complexes is not yet clear [18]. These data argue that Ten $1 p$ stimulates the DNA-binding activity of Cdc13p, and the DNA-binding activity of Ten $1 p$ is unlikely to contribute to the increase of the DNA-binding activity of the protein complex.

We also performed gel-filtration assay to examine the ternary complex formation of Ten1p-Cdc13p-DNA. The mixture of Ten $1 \mathrm{p} / \mathrm{Cdc} 13 \mathrm{p} / \mathrm{TG} 15$ at a molecular ratio of 14:1:2 was analyzed on the Superdex 200 analytical gelfiltration column, and the elution of Cdc13p and Ten $1 p$ was examined by western blot. In addition to an apparent peak at fraction 32, Ten $1 p$ was also co-fractioned with Cdc13p (Figure 3D lower panel) that peaked at fraction 18 (Figure 3D upper panel), but the amount of Ten $1 \mathrm{p}$ co-eluted with Cdc13p (fractions 18 to 20) was not increased by the TG15 DNA (compare Figure 3D with Figure $2 \mathrm{C}$ ). The same result was observed when TG20 was used (data not shown). These data support the argument that Ten $1 \mathrm{p}$ interacts with $\mathrm{Cdc} 13 \mathrm{p}$ to promote the telomeric single-stranded DNA-binding activity of Cdc13p.

Because the DNA-binding domain of Cdc13p (451693 ) had been purified (Figure 4A, right panel) $[16,18]$, we carried out an EMSA assay with purified Cdc13(451693)p in the presence of $2.8 \mu \mathrm{M}$ of Ten $1 \mathrm{p}$ (Figure 4B), the concentration at which Ten1p-DNA interaction was not detected. The Kds of Cdc13(451-693)p for TG20 are 28.6 and $19.3 \mathrm{nM}$, respectively, in the absence and presence of $2.8 \mu \mathrm{M}$ of Ten1p (Figure $4 \mathrm{C}$ ), and they are comparable to that of full-length Cdc13p (28.6 nM) (Figure $3 \mathrm{~A})$. These results indicate that the DNA-binding activity of Cdc13(451-693)p is not stimulated by Ten1p, and the stimulation effect of Ten $1 p$ on $\mathrm{Cdc} 13 p$ requires other domains in addition to the DNA-binding domain of Cdc13p.

\section{Screening Ten 1 mutants that confer deregulated telom- eres by site-directed mutagenesis}

To address whether the stimulation of Ten $1 \mathrm{p}$ on Cdc13p DNA binding is functionally significant in vivo, we sought to identify the separation-of-function mutant allele(s) of ten 1. We arbitrarily chose 21 sites in TEN1 coding region to perform site-directed mutagenesis, and the mutant alleles were sequentially designated as ten 150 to -70 (Figure 5A and Table 1). In all cases of mutagenesis, positively charged lysine $(\mathrm{K})$ or arginine $(\mathrm{R})$ was changed to negatively charged glutamate (E), and negatively charged glutamate (E) or aspartate (D) was changed to positively charged lysine (K). Non-charged 
A

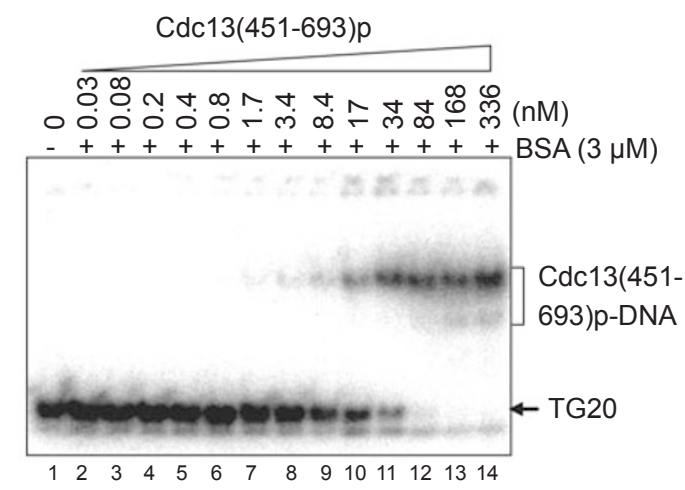

B

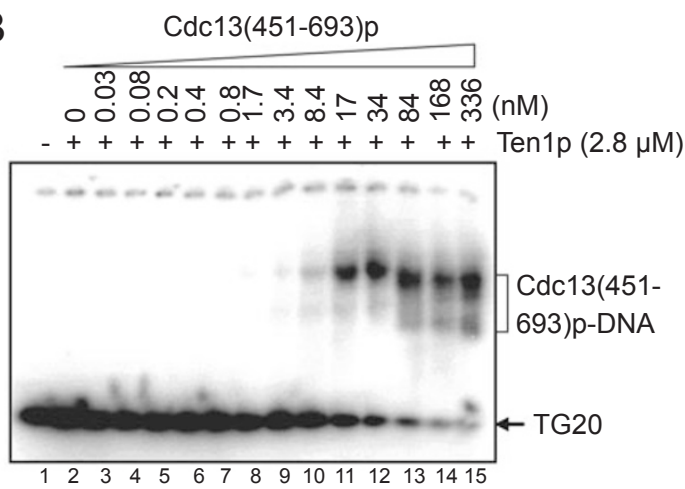

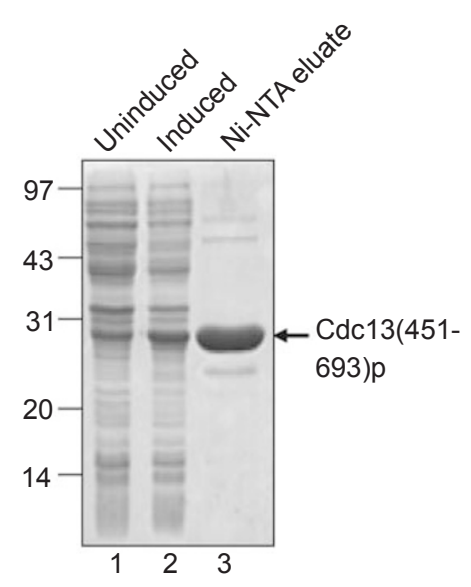

C

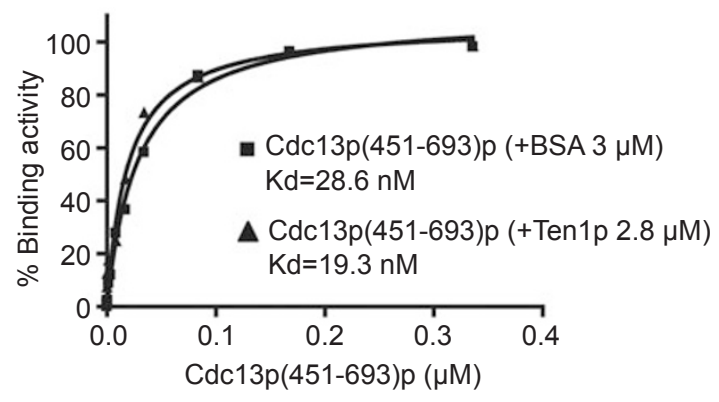

Figure 4 Ten1p does not stimulate the DNA-binding activity of Cdc13(451-693)p. (A) Binding of Cdc13(451-693)p to singlestranded telomeric TG20 DNA. The purified Cdc13(451-693)p (right panel) at different concentrations as indicated on top of the gel was incubated with $2.4 \mathrm{nM}$ of ${ }^{32} \mathrm{P}$-labeled TG20, and their binding activity was examined as in Figure 3 . (B) The effect of Ten $1 p$ on the binding activity of Cdc13(451-693)p to TG20 DNA. A total of 2.4 nM of ${ }^{32}$ P-labeled TG20, the purified Ten1p $(2.8 \mu \mathrm{M})$ and $\mathrm{Cdc13p}(451-693) p$ at different concentrations (indicated on top of the gel) were incubated, and the protein-DNA complexes were examined by EMSA. (C) Comparison of the TG20 DNA-binding affinity of Cdc13(451-693)p with ( $\mathbf{\Delta}$ ) or without (ם) Ten1p as in Figure 3.

and aromatic side chain phenylalanine $(\mathrm{F})$ and tryptophan (W) were changed to alanine (A) (Figure 5A and Table 1). The mutants, such as ten 1-53 (K40E), ten1-54 (R41E), ten 1-64 (D110K) and ten 1-65 (R112E), which could not form colonies on 5-FOA plate, were judged as lethal mutant, and they were not further characterized. The mutants that could be passaged on 5-FOA plate were analyzed by telomere blot (Figure 5B and Table 1). Several mutants, i.e. ten1-55 (R47E), ten1-66 (W116A) and ten1-69 (D138K) exhibited significant telomere elongation (Figure 5B and Table 1); some of the mutants, including ten1-50 (K9E), ten1-51 (K12E), ten1-56 (D50K), ten1-57 (F65A), ten1-58 (R71E), ten1-59 (E83K), ten160 (E84K), ten1-61 (E91K), ten1-63 (F94A), ten1-67 $(\mathrm{F} 131 \mathrm{~A})$ and ten1-68 (K132E) showed subtle telomere lengthening (Figure 5B and Table 1); other mutants, ten1-52 (K14E), ten 1-62 (R92E) and ten 1-70 (R140E) had little or no telomere length change (Figure $5 \mathrm{~B}$, and Table 1). Interestingly, none of the ten 1 mutants displayed any telomere shortening phenotype. Our results were consistent with the observation that Ten $1 p$ plays a negative regulatory role in telomere replication [23]. Because the ten 1-16 (F154I) and ten1-31 (E58K/L76P/ E91V/V115A) mutants reported previously are temperature sensitive, and arrest at the G2/M phase when they are grown at $37{ }^{\circ} \mathrm{C}$ [23], we also examined the temperature sensitivity of the mutant alleles of ten 1-55, -66 and -69 that cause significant longer telomeres. In BY4742 strain, none of the mutants exhibited a growth defect (data not shown), and interestingly, in YPH499 strain, the ten1-69 mutant exhibited a growth defect at high temperature of $37^{\circ} \mathrm{C}$ (Figure 5C). 
A

$\begin{array}{ccccc}50 & 51 & 52 & & 53 \\ 0 & 0 & 0 & \\ \text { MSQLVLDLKC } & \text { LKDKIATNYD } & \text { IHNNVYGGNG } & \text { MEPNIIHPSK } & 40\end{array}$

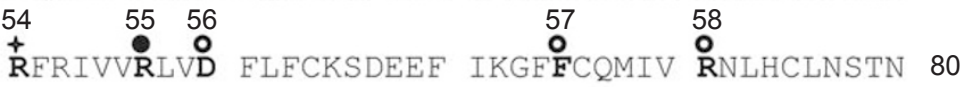

$5960 \quad 616263$

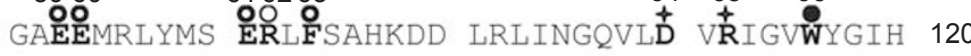

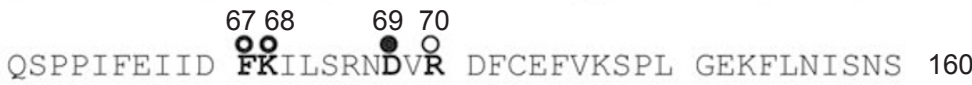

○ Wide type telomere $\quad$ Sightly long telomere

Significantly long telomere + + Lethal

B

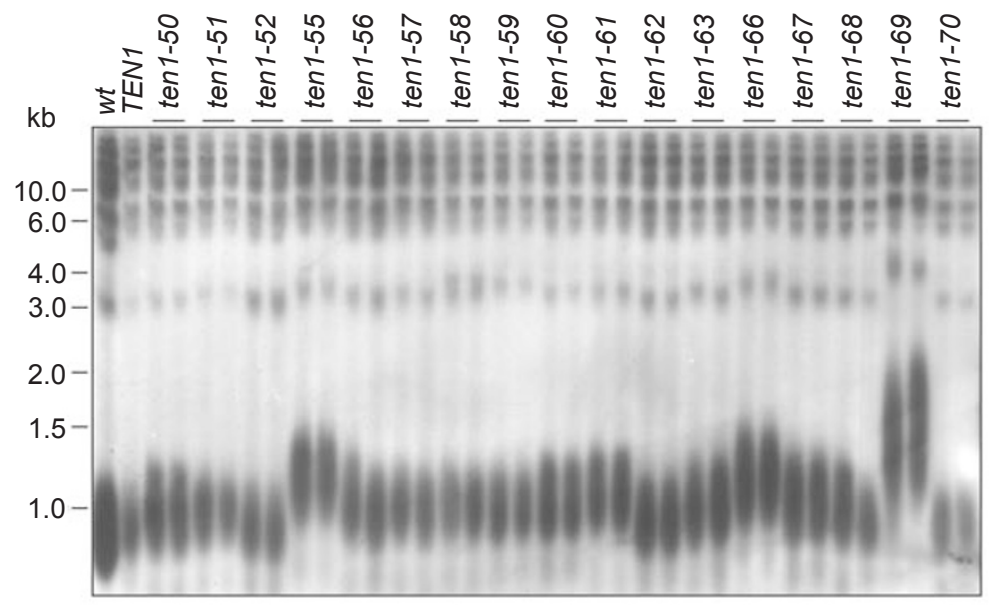

C

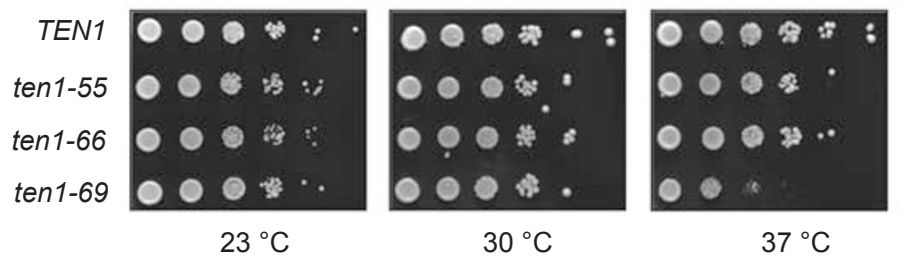

Figure 5 Site-directed mutagenesis of TEN1 and telomere length analysis of mutants. (A) A numerical designation of ten1 point mutant alleles is indicated on the top of the Ten $1 p$ sequence. Telomere length phenotype is indicated by circles. (B) Telomere Southern blot of ten 1 mutants. The genomic DNA from two independent clones of a mutant (labeled on the top of the gel) was digested with Pstl, and hybridized with a telomeric TG probe. (C) Temperature sensitivity analysis of ten1 mutants. The $30^{\circ} \mathrm{C}$ cultured yeast cells of YPH499 background $\left(\mathrm{OD}_{600} 0.5\right)$ were 10 -fold serially diluted, $3 \mu$ l of diluted cells were spotted on the $\mathrm{Leu}^{-} \mathrm{YC}$ plates and the plates were incubated at $23^{\circ} \mathrm{C}, 30^{\circ} \mathrm{C}$ and $37^{\circ} \mathrm{C}$.

Co-immunoprecipitation of Cdc13p and wild-type or mutant Tenlp

To address whether Ten $1 p$ is associated with Cdc13p in vivo, immunoprecipitation experiments were performed in the strains that carry wild-type or mutant TEN1 and 9Myc-tagged CDC13. The polyclonal antibodies (see Materials and Methods) could precipitate both wild-type and mutant Ten $1 \mathrm{p}$ as analyzed by western blot (Figure $6 \mathrm{~A}$, upper panel). The 9Myc-tagged Cdc13p was coprecipitated by wild-type or mutant Ten1p (Figure 6A, lower panel). However, the amount of Cdc13p associated with Ten1p in the ten 1-55 or ten1-66 mutant cells was much less than that in wild-type cells or other tested ten 1 mutants (Figure 6A). These results indicate that Ten $1 \mathrm{p}$ 
Table 1 Summary of the ten 1 mutants.

\begin{tabular}{|c|c|c|c|}
\hline & Mutant & $\begin{array}{l}\text { Amino acid } \\
\text { substitution }\end{array}$ & 'ahenotype \\
\hline \multirow{3}{*}{ Class 1} & ten $1-52$ & K14E & \multirow{3}{*}{ Wide type telomere } \\
\hline & ten $1-62$ & R92E & \\
\hline & ten $1-70$ & R140E & \\
\hline \multirow{11}{*}{ Class 2} & $\operatorname{ten} 1-50$ & K9E & \multirow{11}{*}{$\begin{array}{l}\text { Slightly long telomere } \\
+60 \sim 160 \text { bp }\end{array}$} \\
\hline & ten $1-51$ & $\mathrm{~K} 12 \mathrm{E}$ & \\
\hline & ten $1-56$ & D50K & \\
\hline & ten $1-57$ & F65A & \\
\hline & ten $1-58$ & R71E & \\
\hline & ten $1-59$ & $\mathrm{E} 83 \mathrm{~K}$ & \\
\hline & $\operatorname{ten} 1-60$ & $\mathrm{E} 84 \mathrm{~K}$ & \\
\hline & ten $1-61$ & E91K & \\
\hline & ten $1-63$ & F94A & \\
\hline & $\operatorname{ten} 1-67$ & F131A & \\
\hline & ten $1-68$ & $\mathrm{~K} 132 \mathrm{E}$ & \\
\hline \multirow{3}{*}{ Class 3} & $\operatorname{ten} 1-55$ & R47E & \multirow{3}{*}{$\begin{array}{l}\text { Significantly long telomere } \\
+250 \sim 900 \mathrm{bp}\end{array}$} \\
\hline & $\operatorname{ten} 1-66$ & W116A & \\
\hline & $\operatorname{ten} 1-69$ & D138K & \\
\hline \multirow{4}{*}{ Class 4} & ten $1-53$ & $\mathrm{~K} 40 \mathrm{E}$ & \multirow{4}{*}{ NT } \\
\hline & ten $1-54$ & $\mathrm{R} 41 \mathrm{E}$ & \\
\hline & ten $1-54$ & D110K & \\
\hline & ten $1-65$ & R112E & \\
\hline
\end{tabular}

${ }^{a}$ Telomere length was quantified with Imagequant TL software. Telomeres are $0-60 \mathrm{bp}$ longer than wild type: class 1 wild-type telomere; 60-160 bp longer: class 2 slightly long telomere; 250-900 bp longer: class 3 significantly long telomere; NT: class 4 not tested because of lethality.

interacts with Cdc13p in vivo, and their association is impaired in ten 1-55 or ten1-66 mutant cells.

Since Ten $1 \mathrm{p}$ is associated with $\operatorname{Stn} 1 \mathrm{p}$ in vivo $[9,23-$ $25]$, we tested whether the interaction of Ten $1 \mathrm{p}$ and Stn1p was affected in these ten 1 mutants. The results shown in Figure 6B revealed that the 9Myc-tagged Stn $1 \mathrm{p}$ could be efficiently co-immunoprecipitated by Ten $1 \mathrm{p}$ in TEN1, ten 1-52, ten1-62, ten1-70, ten1-55, ten1-66, but not in ten 1-69 cells. These data support the argument that the defective association of Ten $1 p$ and Cdc13p in ten 1-55 or ten1-66 mutant is not due to an impaired interaction between Ten1p and Stn1p, and Stn1p is not essential for bridging the interaction of Cdc13p and Ten1p [9].

Ten1-55 and Ten1-66 mutant proteins lose their stimulating effect on Cdc13p DNA-binding activity

Since the ten 1-55, -66 and -69 mutant cells have longer telomeres, while ten 1-52,-62 and -70 mutant cells show wild-type telomere length, we tested whether the deregulated telomeres were caused by a defect in the ability of Ten $1 p$ to stimulate Cdc13p. Therefore, we overexpressed and purified recombinant Ten 1 mutants. Briefly, GST-fused Ten1p was overexpressed in E. coli (Figure 7A, lane 2), and purified through a glutathioneaffinity column. The GST-tag was cleaved by PreScission Protease (Figure 7A, lane 3). The recombinant Ten $1 p$ released from the beads-bound GST-tag was further passed through a Q-sepharose column to remove additional contaminations (Figure 7A, lane 4). After these steps of preparation, the recombinant Ten $1 \mathrm{p}$ and its mutants were purified to near homogeneity (Figure 7A, lanes 4-9). All the purified proteins were concentrated to $1 \mu \mathrm{g} / \mu \mathrm{l}$. In Figure 7A, lower panel, lanes 1-3, the highest band recognized by anti-Ten $1 \mathrm{p}$ antibodies could be a chaperon because the antigen used to immunize rabbit was also contaminated by the molecular chaperon of $E$. coli (data not shown). Although Ten1-69p was overexpressed in $E$. coli, we encountered difficulties in obtaining enough

A

IP: anti-Ten1p Ab

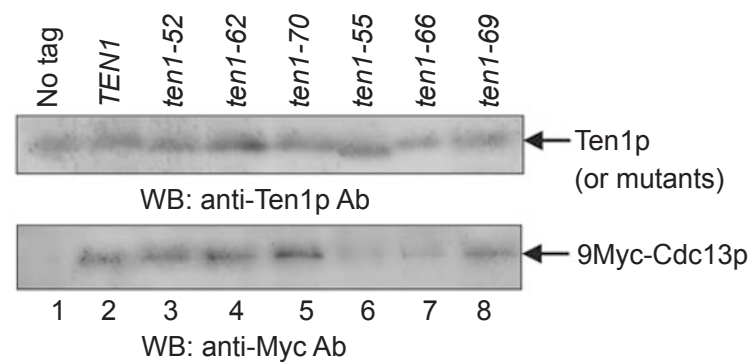

B

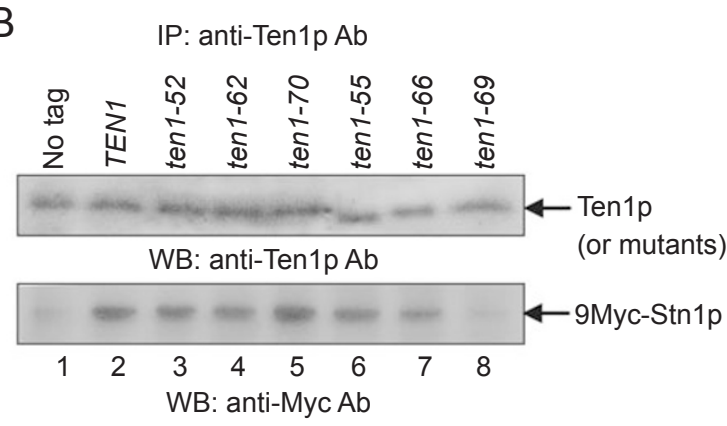

Figure 6 Co-immunoprecipitation of Ten 1 and 9Myc-Cdc13p or 9 Myc-Stn1p. Protein extracts were prepared from cells of the indicated genotype, and Ten $1 p$ was immunoprecipitated (upper panels in $\mathbf{A}$ and $\mathbf{B}$ ) as described in Materials and Methods, and examined by western blot with anti-Ten 1 antibodies. The coimmunoprecipation of 9Myc-Cdc13p (lower panel in A) or 9MycStn1p (lower panel in B) was examined by western blot with anti-Myc antibodies. A strain lacking a Myc-tagged $C D C 13$ or STN1 gene was used as a control. 


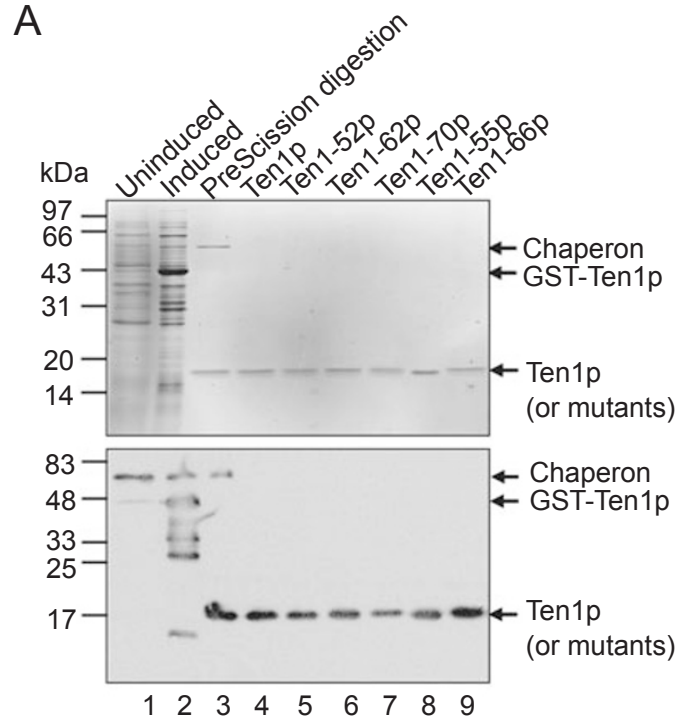

B

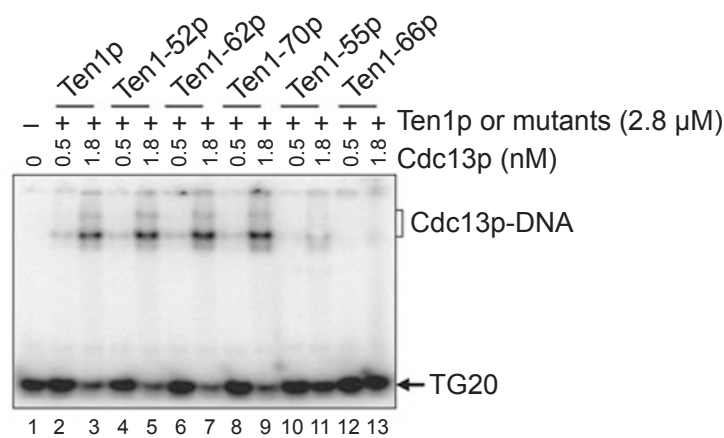

Figure 7 The recombinant Ten1-55p and Ten1-66p fail to promote the DNA-binding activity of Cdc13p. (A) Purification of recombinant wild-type and mutant Ten1 proteins in E. coli. The wild-type and mutant Ten1p was examined by Coomassie bluestained SDS-PAGE (upper panel) and western blot with antiTen1 antibodies (lower panel). (B) The effect of mutant Ten1 proteins on the binding activity of Cdc13p to TG20 DNA. ${ }^{32} \mathrm{P}$ labeled TG20 (2.4 nM), the purified wild-type or mutant Ten1 proteins $(2.8 \mu \mathrm{M})$ and Cdc13p (0.5 or $1.8 \mathrm{nM}$ as indicated on top of the gel) were incubated, and the protein-DNA complexes were examined by EMSA.

Ten1-69p for further biochemical assay.

The purified mutant proteins, including Ten 1-52p, Ten1-62p, Ten1-70p, Ten1-55p and Ten1-66p were used in an EMSA assay of Cdc13p. In the presence of $2.8 \mu \mathrm{M}$ of Ten1-52p, Ten1-62p or Ten1-70p, the Cdc13p-DNA complex was detected when the Cdc13p was at both 0.5 $\mathrm{nM}$ and $1.8 \mathrm{nM}$ (Figure 7B, lanes 4-9). Thus, the stimulatory effect of Ten $1-52 p$, Ten1-62p or Ten1-70p was the same as that of the wild-type Ten1p (Figure 7B, lanes 2 and 3). But in the presence of $2.8 \mu \mathrm{M}$ of Ten1-55p or Ten1-66p, the Cdc13p-DNA complex was barely detect- able when the concentration of Cdc13p was at $1.8 \mathrm{nM}$ (Figure 7B, lanes 11 and 13), and undetectable at $0.5 \mathrm{nM}$ (Figure 7B, lanes 10 and 12). These results suggest that Ten1-55 or Ten1-66 mutant protein possesses a reduced activity in promoting the DNA binding of Cdc13p in vitro. Because ten 1-55 or ten1-66 mutant exhibits longer telomere than wild-type, ten 1-52, ten 1-62 or ten 1-70 mutants (Figure 5B), we argued that the stimulating activity of Ten1p on Cdc13p DNA binding is important for the telomere length regulation. This result is consistent with the observations reported previously by Grandin et al. [28] that the $c d c 13-109$ and $c d c 13-231$ mutants exhibit elongated telomeres, and the mutant $\mathrm{Cdc} 13$ proteins have weaker DNA-binding activity .

To examine whether the telomere binding of $\mathrm{Cdc} 13 \mathrm{p}$ is affected by ten 1 mutation in vivo, chromatin immunoprecipitation (ChIP) assays were performed in the ten 1 mutant cells. In the negative control of untagged strain, no enrichment of TEL was detected (Figure 8A, lane 1).
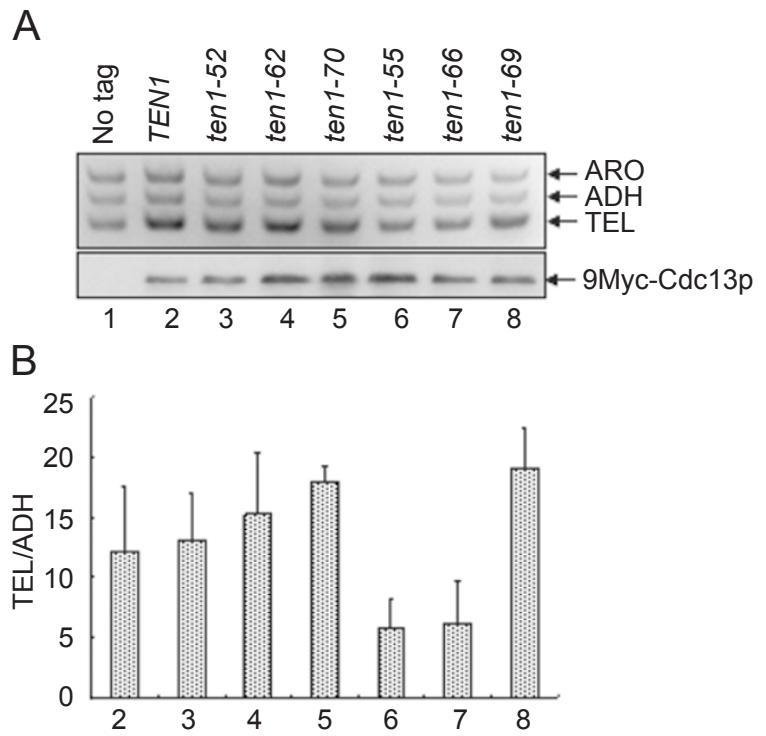

Figure 8 The telomere binding of Cdc13p is decreased in the ten1-55 or ten1-66 mutant cells. Chromatin immunoprecipitations were performed in wild-type and mutant ten 1 strains in which URA3 gene was integrated next to the left telomere of chromosome VII and the chromosomal CDC13 gene was tagged with 9-Myc epitope at its carboxyl end. Multiplex PCR was carried out with primer pairs specific for telomeric (TEL), subtelomeric $(\mathrm{ADH})$ or nontelomeric (ARO) chromosomal loci (A, upper panel). The precipitated 9Myc-Cdc13p was examined by western blot using anti-Myc antibody (A, lower panel). The isogenic strains are labeled on top of the panel. The telomere binding of Cdc13p in wild-type and ten 1 mutant strains were quantified using Scion Image software (B). The bars represent the ratio of TEL to ADH. Error bars represent the standard deviation from three independent experiments. 
The telomere binding of Cdc13p in ten 1-52, ten 1-62, ten 1-69 or ten 1-70 cells was at the same level as in wildtype cells (Figure 8A, lanes 2-5 and 8, and Figure 8B). About 2-3-fold decrease in telomere binding of Cdc13p was observed in ten 1-55 or ten 1-66 cells (Figure 8A, lanes 6 and 7, and Figure 8B). These results suggest that telomere elongation in ten 1-55 or ten 1-66 cells may result from a decrease of DNA binding of Cdc13p.

\section{Discussion}

Telomere length regulation has been one of the central topics in telomere biology. Deregulated telomere length may cause genome instability. In S. cerevisiae, the Cd$\mathrm{c} 13 \mathrm{p} / \mathrm{Stn} 1 \mathrm{p} / \mathrm{Ten} 1 \mathrm{p}$ heterotrimeric complex represents an RPA-like telomere-binding machinery [9]. Cdc13p is the major telomeric single-stranded DNA-binding protein. It not only acts as a positive regulator of telomere replication by recruiting telomerase, but also functions as a negative regulator of telomeric DNA elongation [1, 28, 29]. Its negative regulatory role appears to be coupled with both Stn 1 and Ten 1 because quite a few temperaturesensitive mutants of CDC13, STN1 and TEN1 exhibit elongated telomeres at the semi-permissive temperature [10, 21-23]. Cdc13p binds to telomeres in all phases of the cell cycle, and this association increases during late S-phase [12], suggesting that the binding of Cdc13p to telomeres is regulated. In this work, we report that Ten $1 p$ promotes the DNA-binding activity of Cdc13p. Our finding may provide an explanation for the role of Ten $1 p$ in the negative regulation of telomere length.

The recombinant Cdc13p and Ten $1 \mathrm{p}$ co-overexpressed in insect cells were co-fractionated (Figure 1B). A gelfiltration analysis also showed co-elution of Cdc13p and Ten $1 p$ (Figure 2C). Immunoprecipitation of Ten $1 p$ also co-pulled down Cdc13p (Figure 6A). These results are consistent with the previous finding that Ten $1 p$ interacts with Cdc13p in yeast two-hybrid analysis [23], and strongly suggest that Cdc13p interacts with Ten1p directly. The R47E (Ten1-55p) or W116A (Ten1-66p) mutation in Ten $1 p$ causes a defective interaction with Cdc13p (Figure 6A), but does not affect its interaction with Stn1p (Figure 6B). In contrast, the Ten1-69 mutant protein loses its interaction with Stn1p (Figure 6B) but still associates with Cdc13p (Figure 6A). These observations suggest that $\operatorname{Stn} 1 \mathrm{p}$ is not a prerequisite for the Cdc13p-Ten $1 p$ interaction. However, the Cdc13p-Ten $1 p$ complex is unstable (Figure 2C), and the mutation in Ten1-55p, -66p or $-69 p$ that affects its interaction with either Cdc13p or Stn $1 p$ causes longer telomeres (Figure 5B), supporting the argument that the regulated association of Cdc13p, $\mathrm{Stn} 1 \mathrm{p}$ and Ten $1 \mathrm{p}$ is important for telomere length regula- tion $[9,23]$.

The binding affinity of the Cdc13p-Ten $1 p$ complex to telomeric $\mathrm{TG}_{1-3}$ DNA is stimulated by Ten1p (Figure 3). We could not rule out the possibility that the enhanced of DNA-binding activity of the Cdc13p-Ten1p complex is also attributed to the DNA-binding activity of Ten1p. However, several lines of evidence seem to support the argument that Ten $1 p$ enhances the DNA-binding activity of Cdc13p. Ten1p itself interacts with DNA poorly (Figure 1D). The DNA-binding activity of the Cdc13 DNA-binding domain, Cdc13(451-693)p, is not affected by Ten1p (Figure 4). The binding of Cdc13p to TG15, which is an optimal substrate for full-length Cdc13p, is promoted by Ten $1 p$ (Figure 3C). These results also lead to a hypothesis that the association of Ten $1 p$ with $\mathrm{Cdc} 13 \mathrm{p}$ may contribute to the regulation of $\mathrm{Cdc} 13 p$ telomere binding. The Ten1-55 and Ten1-66 mutant proteins lose their ability to promote the DNA-binding activity of Cdc13p in vitro (Figure 7B). In the ten1-55 or ten1-66 mutant cells, the interaction between Ten $1 p$ and Cdc13p is significantly decreased (Figure 6A). Consequently, the telomere binding of Cdc13p in the ten1-55 or ten 1-66 mutant cells is decreased (Figure 8), and telomeres are elongated (Figure 5B). In the $c d c 13-109$ and $c d c 13-231$ mutants reported previously by Grandin et al. [28], telomere binding of Cdc13p is decreased, and telomeres are elongated. Therefore, it is likely that decrease of Cdc13p telomerebinding activity that resulted from either mutation of Cdc13p or defective Cdc13p-Ten1p interaction (e.g., in ten 1-55 and -66 mutants) could cause telomere elongation. It is unclear whether the telomeres in the ten $1-55$ or ten 1-66 mutant cells are intactly capped. Unlike the ten 116 and ten 1-31 mutants [23], the ten 1-55 and ten 1-66 mutants could survive at $37^{\circ} \mathrm{C}$, suggesting that telomere capping in these mutants is not affected, and the Ten $1 p$ Cdc13p interaction may not be essential for cell viability.

Previous studies show that $\mathrm{Cdc} 13 \mathrm{p}$ plays dual roles in telomere maintenance $[1,29]$. The telomere association of Cdc13p increases in late S-phase when Est1p is recruited to activate telomerase [12]. This represents the positive regulatory function of $\mathrm{Cdc} 13 \mathrm{p}$. The negative regulatory role of $\mathrm{Cdc13p}$ in telomere length regulation has been associated with Stn1p and Ten1p [21, 23, 24, 28, 29]. Our observation that Ten1p stimulates Cdc13p DNA-binding activity may provide a mechanistic explanation. One scenario could be that Ten $1 \mathrm{p}$ interacts with Cdc13p in late S-phase to promote Cdc13p binding to telomeric G-strand and thereby prevent telomerase from further elongating telomeres. The fact that some ten 1 mutants, including ten1-55 and ten1-66, exhibit longer telomeres supports this hypothesis. Since there exist interactions between Ten1p and Stn1p (Figure 1B and 6B) 
[9, 23-26], Stn1p and Pola [25, 30], as well as Cdc13p and Pola [19], another possibility could be that the interaction of Ten $1 \mathrm{p}$ and Cdc13p tightens the binding of Cdc13p to telomeric G-strand to slow down the C-strand synthesis.

\section{Materials and Methods}

\section{Strains, plasmids and mutagenesis}

The pRS316-TEN1 or pRS315-TEN1 centromere plasmid was constructed by cloning a 4 483-bp fragment, which contains the Ten $1 \mathrm{p}$ coding region, and its upstream and downstream regions into the BamHI-XhoI sites of pRS316 or pRS315. Mutants of TEN1 were created by site-directed mutagenesis.

All the in vivo experiments were in either YPH499 (MATa

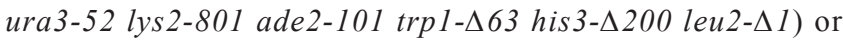
BY4742 (MATa his $3 \Delta 1$ leu $2 \Delta 0$ lys $2 \Delta 0$ ura $3 \Delta 0$ ) background. For the immunoprecipitation and ChIP analysis, a 9Myc-tag was inserted at the carboxyl terminus of the chromosomal copy of $C D C 13$ or $S T N 1$. Because $T E N 1$ is an essential gene, the wild-type or mutant allele of TEN1 in a CEN plasmid pRS315 was introduced into a heterozygous diploid strain (ten $1 \triangle \because: k a n M X 4 / T E N 1)$. The haploid strain with the wild-type or mutant copy of TEN1 was obtained by tetrad dissection.

A heterozygous diploid strain for TEN1 (Mat a/a; his $3 \Delta 1 /$

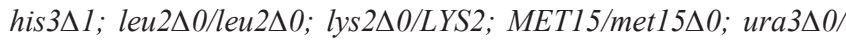
ura $3 \Delta 0$; ten $1 \Delta .:$ kanMX4/TEN1) derived from BY4743 was purchased from Euroscarf (Frankfurt, Germany). pRS316-TEN1 plasmid was introduced and tetrad dissection was carried out to obtain the haploid strain that contains a single copy of TEN1 in pRS316 plasmid (URA3 marker) instead of endogenous TEN1. The mutant allele of ten 1 in a $C E N$ plasmid pRS315 was introduced into a haploid strain that contains a single copy of TEN1 in pRS316 plasmid (URA3 marker). The wild-type copy of TEN1 was counter-selected on a 5 -FOA plate.

\section{Telomere blot}

Two independent colonies of each mutant were isolated and tested for its function on telomere length regulation. Genomic DNA prepared from saturated yeast cultures of each strain was digested with PstI, separated by $1 \%$ agarose gel and transferred to HyBond $\mathrm{N}+$ membrane (Amersham Pharmacia Biotech), crosslinked by $\mathrm{UV}$ and then probed with a $\mathrm{TG}_{1-3}$ telomeric probe as previously documented [31].

\section{Recombinant baculovirus preparation}

The coding region of STN1 gene (1485-bp) was PCR amplified with primers containing Bam HI and HindIII restriction sites, and inserted into pBlueBac4-6His plasmid [18]. The coding region of TEN1 gene (483-bp) was PCR amplified with primers containing NdeI and XhoI restriction sites, and inserted into pBlueBac4 plasmid (Invitrogen). The resulting plasmids, pBlueBac4-6HisSTN1 and pBlueBac4-TEN1 were confirmed by DNA sequencing. To produce recombinant virus, plasmid pBluebac4-6His-STN1 or pBlueBac4-TEN1 DNA and Bac-N-Blue virus DNA (Invitrogen) were co-transfected into $\mathrm{Sf} 9$ cells, and plaque assay was performed to generate pure population of recombinant virus particles by following the Invitrogen protocols. The presence of an insert in a putative recombinant virus was determined by PCR using primers, which are complementary to the polyhedron loci. Positive recombinant viruses were amplified in $\mathrm{Sf} 9$ cells to a titer of about $10^{8}$ plaque formation units $/ \mathrm{ml}$. The recombinant virus that expressed His-tagged Cdc13p was prepared as reported previously [18].

Overexpression and co-overexpression of recombinant Ten1p, His-tagged Stn1p and His-tagged Cdc13p in insect cells

Sf9 cells were grown to $80 \%$ confluence in $100-\mathrm{mm}$ dishes at $27{ }^{\circ} \mathrm{C}$ in Grace's medium supplemented with $10 \%$ fetal bovine serum and $50 \mu \mathrm{g} / \mathrm{ml}$ Gentamycin, and infected at a multiplicity of infection (MOI) of 10 with recombinant virus for Ten1, Stn1 or Cdc13, or co-infected at an MOI of 5 with recombinant viruses for Ten1, Stn1 and Cdc13 as indicated. Cells were harvested at $60 \mathrm{~h}$ post-infection, and expression of recombinant Ten1p, His-tagged Stn $1 p$ and His-tagged Cdc13p were analyzed by immunoblotting with antibodies against Stn1p, Ten1p and Cdc13p, respectively (see preparations of polyclonal antibodies against Cdc13p, Stn1p and Ten1p).

\section{Co-fractionation of Ten1p and His-Stn1p or His-Cdc13p}

To detect the physical interaction between Ten $1 \mathrm{p}$ and Histagged Stn1p or His-tagged Cdc13p, $\sim 3 \times 10^{8} \mathrm{Sf} 9$ cells were coinfected at an MOI of 5 with recombinant viruses of Ten1 and Stn1 or Cdc13, respectively. Cells were harvested at $60 \mathrm{~h}$ post-infection, and resuspended in $30 \mathrm{ml}$ of lysis buffer $(50 \mathrm{mM}$ Tris- $\mathrm{Cl}, \mathrm{pH} 7.8$, $150 \mathrm{mM} \mathrm{NaCl}, 5 \mathrm{mM} \beta$-mercaptoethanol, $1 \mathrm{mM}$ phenylmethylsulfonyl fluoride (PMSF)) and the cell contents were released with sonication. The disrupted cells were centrifuged at $16000 \mathrm{~g}$ for 30 min at $4{ }^{\circ} \mathrm{C}$. The cell extract was subjected to nickel beads (Qiagen) pre-equilibrated with a $50 \mathrm{mM}$ Tris-Cl buffer $(\mathrm{pH} 7.8)$ containing $150 \mathrm{mM} \mathrm{NaCl}, 5 \mathrm{mM} \beta$-mercaptoethanol and $1 \mathrm{mM}$ PMSF. The beads were washed and the proteins bound to beads were analyzed by western blot using antibodies against Cdc13p, Stn1p and Ten1p.

\section{Purification of recombinant His-tagged Ten1 in Escherichia coli}

To express Ten $1 \mathrm{p}$ in E. coli, the coding region of TEN1 was cloned in pET22b at the NdeI-XhoI sites. The resulting plasmid was transformed into BL21 (DE3) host strain. The overexpression of recombinant His-tagged Ten $1 p$ after isopropyl-b-D-thiogalactopyranoside (IPTG) induction was examined by SDS-PAGE and western blot with primary antibodies against Ten1p. To purify Histagged Ten1p, a 9-1 culture of E. coli harboring pET22b-TEN1 plasmid was grown at $37^{\circ} \mathrm{C}$ to $\mathrm{OD}_{600} 0.4$ and induced with the addition of $0.3 \mathrm{mM}$ IPTG. The cells were grown at $16^{\circ} \mathrm{C}$ overnight before harvesting by centrifugation. Cells were resuspended in $300 \mathrm{ml}$ of lysis buffer $(50 \mathrm{mM}$ Tris- $\mathrm{HCl}, \mathrm{pH} 7.8,150 \mathrm{mM} \mathrm{NaCl}$ and $1 \mathrm{mM}$ PMSF) and the cell contents were released with a cell disrupter (Avestin EF-C5). The disrupted cells were centrifuged at $16000 \mathrm{~g}$ for $30 \mathrm{~min}$ at $4{ }^{\circ} \mathrm{C}$ to obtain total cell extracts. In total, $4 \mathrm{ml}$ of Ni-NTA (Qiagen) was added to the total cell extracts and incubated at $4{ }^{\circ} \mathrm{C}$ for $3 \mathrm{~h}$. The resin was washed with buffer containing $50 \mathrm{mM}$ Tris- $\mathrm{Cl}$ (pH 7.8), $300 \mathrm{mM} \mathrm{NaCl}, 20 \mathrm{mM}$ imidazole and eluted with $12 \mathrm{ml}$ of buffer containing $50 \mathrm{mM}$ Tris- $\mathrm{Cl}(\mathrm{pH}$ 7.8), $250 \mathrm{mM}$ imidazole and $10 \%$ glycerol. After dialysis with a buffer (50 mM Tris-Cl, pH 7.8, $50 \mathrm{mM} \mathrm{NaCl}, 1 \mathrm{mM}$ EDTA, $1 \mathrm{mM}$ dithiothreitol and $10 \%$ glycerol) overnight, protein was subjected 
to a $5 \mathrm{ml}$ of HiTrap heparin column (Amersham Biosciences). Protein was eluted with $150 \mathrm{ml}$ elution buffer (50 mM Tris-Cl, $\mathrm{pH}$ 7.8, $1 \mathrm{mM}$ EDTA, $1 \mathrm{mM}$ dithiothreitol, and 5\% glycerol) with a linear gradient of $\mathrm{NaCl}$ from 80 to $600 \mathrm{mM}$. Peak fractions that contained Ten $1 \mathrm{p}$ were concentrated to $0.4 \mu \mathrm{g} / \mu \mathrm{l}$, aliquoted and frozen in liquid nitrogen and stored at $-80{ }^{\circ} \mathrm{C}$. The yield of Ten $1 \mathrm{p}$ was $\sim 0.3 \mathrm{mg}$ from 11 of $E$. coli culture.

Purification of recombinant wild-type or mutant Ten1p in GST-expression system in Escherichia coli

The coding region of TEN1 was cloned into pGEX-6P-1 plasmid at the BamHI-XhoI sites. Mutants of TENI were created as in pRS315 plasmid. The resulting plasmid was transformed into BL21 (DE3) host strain for expression. A 9-1 culture of E. coli harboring pGEX-6P-1-TEN1 (or its mutant) plasmid was grown at $37^{\circ} \mathrm{C}$ to $\mathrm{OD}_{600} 0.4$, and induced with $0.3 \mathrm{mM}$ IPTG at $16^{\circ} \mathrm{C}$ overnight before harvesting by centrifugation. Cells were resuspended in $300 \mathrm{ml}$ of lysis buffer $(50 \mathrm{mM}$ Tris- $\mathrm{HCl}$, pH $7.8,150 \mathrm{mM} \mathrm{NaCl}$, $1 \mathrm{mM}$ DTT, $1 \mathrm{mM}$ EDTA and $1 \mathrm{mM}$ PMSF) and lysed with a cell disrupter (Avestin EF-C5). All purification procedures were carried out at $4{ }^{\circ} \mathrm{C}$. The total soluble fraction was recovered by centrifugation at $36000 \mathrm{~g}$ for $60 \mathrm{~min}$, and loaded onto $10 \mathrm{ml}$ of glutathione sepharose beads (Amersham Biosciences). The resin was washed with $2 \mathrm{M} \mathrm{NaCl}$ high salt buffer (50 mM Tris-HCl, $\mathrm{pH} 7.8,1 \mathrm{mM}$ DTT, $1 \mathrm{mM}$ EDTA, $10 \%$ glycerol) and subsequently with $50 \mathrm{mM}$ $\mathrm{NaCl}$ low salt buffer. The GST-fused Ten1p bound to GST beads was digested for $16 \mathrm{~h}$ with PreScission Protease. The digested protein in low salt buffer was subjected to $1 \mathrm{ml}$ of Hi-Trap Q sepharose column (Amersham Biosciences). The flowthrough that contained Ten $1 \mathrm{p}$ was analyzed by Coomassie blue-stained SDSPAGE. The purified Ten $1 \mathrm{p}$ was aliquoted and stored at $-80^{\circ} \mathrm{C}$.

Gel-filtration analysis of interaction between purified recombinant Ten $1 p$ and $C d c 13 p$

Gel-filtration analysis was performed on a pre-packaged Superdex 200 column $(10 \times 300 \mathrm{~mm}$, Amersham Biosciences), which was calibrated with protein standards including Ferrin $(440 \mathrm{kDa})$, Albumin (66 kDa), Ovalbumin (43 kDa) and Ribonuclease A (13.7 $\mathrm{kDa})$. The column was equilibrated and developed with the $50 \mathrm{mM}$ Tris- $\mathrm{HCl}$ buffer ( $\mathrm{pH}$ 7.8) containing $50 \mathrm{mM} \mathrm{NaCl}, 1 \mathrm{mM}$ EDTA, $1 \mathrm{mM}$ dithiothreitol and $5 \%$ glycerol at a flow rate of $0.2 \mathrm{ml} / \mathrm{min}$, and fractions of $500 \mu \mathrm{l}$ were collected. A total of $200 \mu \mathrm{l}$ of protein sample was loaded in each run. The amount of proteins that were used in gel-filtration experiments is indicated in the figure legends. The elution of proteins was analyzed by Coomassie blue-stained SDS-PAGE or western blot with appropriate antibodies.

\section{Electrophoretic mobility shift assay}

The oligonucleotides TG20 (5'-TGG TGT GTG TGG GTG TGG TG-3') or TG15 (5'-TGT GTG GGT GTG GTG-3') was labeled with $\left[\gamma^{32}{ }^{32} \mathrm{P}\right] \mathrm{ATP}$ (3 $000 \mathrm{Ci} / \mathrm{mM}$, Amersham Biosciences) using T4 polynucleotide kinase (New England Biolabs) and subsequently purified with MicroSpin G-25 column (Amersham Biosciences). To perform the EMSA assay, the recombinant protein in $50 \mathrm{mM}$ Tris- $\mathrm{HCl}$ buffer (pH 7.5) containing $50 \mathrm{mM} \mathrm{NaCl}, 1 \mathrm{mM}$ EDTA and $1 \mathrm{mM}$ dithiothreitol was mixed with ${ }^{32} \mathrm{P}$-labeled TG20 or TG15 DNA in a total volume of $10 \mu$. The reaction mixture was incubated at $30{ }^{\circ} \mathrm{C}$ for $40 \mathrm{~min}$, and analyzed with a $6 \%$ nondenaturing polyacrylamide gel, which was pre-run at $100 \mathrm{~V}$ for
10 min. Electrophoresis was carried out in TBE buffer ( $89 \mathrm{mM}$ Tris borate, $2 \mathrm{mM}$ EDTA) at $100 \mathrm{~V}$ for $60 \mathrm{~min}$. The gel was dried and autoradiographed with a PhosphorImager screen (Molecular Dynamics). The DNA substrates used in all experiments were at $2.4 \mathrm{nM}$, and the amounts of proteins were indicated in the figure legends. The intensity of bands corresponding to free DNA and protein-DNA complex in each lane was quantified using the Scion Image software. The data were analyzed by nonlinear regression equation using the Graph Pad Prism software and fit one sitespecific-binding model: $\mathrm{Y}=\mathrm{Bmax} \cdot \mathrm{X} /(\mathrm{Kd}+\mathrm{X})$ where $\mathrm{Y}$ is the magnitude of radioactivity bound to the protein, $\mathrm{X}$ is the protein concentration, Bmax is the total change in counts (value at the plateau minus the background counts) and $\mathrm{Kd}$ is the equilibrium binding constant.

\section{Preparations of polyclonal antibodies against Cdc13p, Stnlp and Ten $1 p$}

To prepare the polyclonal antiserum against Ten $1 \mathrm{p}, \operatorname{Stn} 1 \mathrm{p}$ or $C d c 13 p$, the $E$. coli overexpression system was used to obtain the antigens. The preparation of His-Ten1p is as described in "Purification of recombinant Ten1 in E. coli". The 585-bp fragment of the coding region of STN1 gene (900-1 $485 \mathrm{nt}$ ) was PCR amplified with primers containing $B a m \mathrm{HI}$ and $\mathrm{XhoI}$ restriction sites, and inserted into pGEX-4T-1 plasmid to produce GST-Stn1(300-495) p. The 726-bp fragment of the coding region of $C D C 13$ (1-726 nt) was PCR amplified with primers containing BamHI restriction site, and inserted into pGEX-4T-1 plasmid to produce GSTCdc13(1-234)p. The purification of the antigens including HisTen1p, GST-Stn1(300-495)p and GST-Cdc13(1-234)p, the raise of antiserum and the affinity purification of specific antibodies with antigen column were as described previously $[32,33]$.

\section{Co-immunoprecipitation of Ten $1 p$ and $9 M y c-C d c 13 p$ or $9 M y c-\operatorname{Stn} 1 p$}

$50 \mathrm{ml}$ of yeast cells $\left(\mathrm{OD}_{600}\right.$ about 1$)$ were harvested, washed twice with TBS (20 mM Tris- $\mathrm{HC} 1$ at $\mathrm{pH} 7.6,200 \mathrm{mM} \mathrm{NaCl})$ and re-suspended in $500 \mu 1$ lysis buffer ( $50 \mathrm{mM}$ HEPES-KOH at $\mathrm{pH} 7.5$, $140 \mathrm{mM} \mathrm{NaCl}, 1 \mathrm{mM}$ EDTA, 10\% glycerol, 0.05\% NP-40, $1 \mathrm{mM}$ PMSF, $1 \mathrm{mM}$ benzamidine, $10 \mu \mathrm{g} / \mathrm{ml}$ aprotinin, $1 \mu \mathrm{g} / \mathrm{ml}$ leupeptine and $1 \mu \mathrm{g} / \mathrm{ml}$ pepstatin). An equal volume of glass beads (diameter $0.5 \mathrm{~mm}$ ) was added. Breakage was achieved by vortexing on a shaker for $45 \mathrm{~min}$ at $4{ }^{\circ} \mathrm{C}$. The bottom of the tube was punctured and the lysate collected by brief centrifugation. The suspension was clarified by centrifugation at $13000 \mathrm{rpm}$ for $10 \mathrm{~min}$ in a microcentrifuge to yield the whole-cell extract. For immunoprecipitation of Ten $1 p$, the affinity-purified anti-Ten $1 p$ antibody was added to $500 \mu \mathrm{l}$ of whole-cell extract and incubated for $4 \mathrm{~h}$ at $4{ }^{\circ} \mathrm{C}$. A total of $50 \mu 1$ of protein A-Sepharose CL-4B beads (Amersham Biosciences) slurry (1:1) was added, and the incubation continued overnight at $4{ }^{\circ} \mathrm{C}$. The immunoprecipitates were washed thrice for 5 min with $1 \mathrm{ml}$ lysis buffer and subsequently resuspended in 30 $\mu 12 \times$ SDS-PAGE sample buffer. The eluted proteins were analyzed by western blot.

\section{Chromatin immunoprecipitation}

The ChIP experiment was performed as described [34]. Yeast cells were grown on yeast complete medium to an $\mathrm{OD}_{600}$ of $\sim 1$. A total of $50 \mathrm{ml}$ of cells were cross-linked with $1 \%$ formaldehyde for $10 \mathrm{~min}$ at room temperature. Glycine was added to a final concen- 
tration of $125 \mathrm{mM}$ and the incubation continued for $5 \mathrm{~min}$. Cells were harvested and washed twice with TBS, and breakage was performed in $500 \mu 1$ lysis buffer $(50 \mathrm{mM}$ HEPES-KOH at $\mathrm{pH} 7.5$, $140 \mathrm{mM} \mathrm{NaC1}, 1 \mathrm{mM}$ EDTA, 1\% Triton X-100, 0.1\% sodium deoxycholate, $1 \mathrm{mM}$ PMSF, $1 \mathrm{mM}$ benzamidine, $10 \mu \mathrm{g} / \mathrm{ml}$ aprotinin, $1 \mu \mathrm{g} / \mathrm{ml}$ leupeptine and $1 \mu \mathrm{g} / \mathrm{ml}$ pepstatin). The suspension was sonicated thrice for $10 \mathrm{sec}$ each (resulting in an average fragment size of $0.5-1 \mathrm{~kb}$ ) and clarified by centrifugation at $13000 \mathrm{rpm}$ for $5 \mathrm{~min}$ in a microcentrifuge. Immunoprecipitations were performed as described above. Precipitates were successively washed for 5 min each with $1 \mathrm{ml}$ of lysis buffer, $1 \mathrm{ml}$ of lysis buffer containing $500 \mathrm{mM} \mathrm{NaC1}, 1 \mathrm{ml}$ of wash buffer $(10 \mathrm{mM}$ Tris- $\mathrm{HCl}$ at $\mathrm{pH}$ 8.0, 0.25 M LiC1, 0.5\% NP-40, 0.5\% sodium deoxycholate, 1 $\mathrm{mM}$ EDTA) and $1 \mathrm{ml}$ of TE (20 mM Tris-HC1 at $\mathrm{pH} 8.0,1 \mathrm{mM}$ EDTA). The samples were eluted with $145 \mu \mathrm{l}$ of $50 \mathrm{mM}$ Tris-HC1 at $\mathrm{pH} 8.0,10 \mathrm{mM}$ EDTA, $1 \%$ SDS. In total, $120 \mu 1$ of eluate was decrosslinked at $65{ }^{\circ} \mathrm{C}$ for about $7 \mathrm{~h}$ and then treated with $1 \mu \mathrm{g} /$ $\mu l$ proteinase K for $2 \mathrm{~h}$. Finally, QIAquick PCR Purification kit (Qiagen) was used to purify the immunoprecipitated DNA. PCR reactions were carried out in $30 \mu \mathrm{l}$ volume with $1 / 60$ of the immunoprecipitated material, Ex-Taq polymerase (TaKaRa) and the corresponding buffer system was used. The following primers [34] were used in the multiplex PCR: TEL: 5'-GAC ATT ATT ATT GTT GGA AGA GGA CTA TTT GC-3' and 5'-CTT GAA GCT CTA ATT TGT GAG GAT ATC C-3'; ADH:5'-GGA CGA CAA ATC CTC ATA ATA TGA ATT AGG-3' and 5'-CAG GGA GAG GAA ATG ATA AAA TAA GTT ACG-3'; ARO:5'-TGA CTG GTA CTA CCG TAA CGG TTC-3' and 5'-GAA TAC CAT CTG GTA ATT CTG TAG TTT TGA C-3'. An initial denaturation for $3 \mathrm{~min}$ at $94{ }^{\circ} \mathrm{C}$ was followed by 28 cycles with denaturation for $45 \mathrm{sec}$ at $94{ }^{\circ} \mathrm{C}$, annealing for $2 \mathrm{~min}$ at $61{ }^{\circ} \mathrm{C}$, polymerization for $2 \mathrm{~min}$ at $72{ }^{\circ} \mathrm{C}$ and a final extension for $10 \mathrm{~min}$ at $72{ }^{\circ} \mathrm{C}$. PCR products were separated on a $2.5 \%$ agarose gel and visualized by ethidium bromide staining. The PCR bands were quantified by Scion Image software.

\section{Acknowledgments}

We thank Ms Lu-Xia Xu for the help in antibody preparation, and other members in the Zhou lab. This work is supported by a Chinese Academy of Sciences-Max Planck Society Professorship, and grants from the National Natural Science Foundation of China (NSFC 30630018) and the Ministry of Science and Technology of China (2007CB914502).

\section{References}

1 Evans SK, Lundblad V. Positive and negative regulation of telomerase access to the telomere. J Cell Sci 2000; 113:33573364 .

2 Blackburn EH. Telomere states and cell fates. Nature 2000; 408:53-56.

3 Collins K. The biogenesis and regulation of telomerase holoenzymes. Nat Rev Mol Cell Biol 2006; 7:484-494.

4 Smogorzewska A, de Lange T. Regulation of telomerase by telomeric proteins. Annu Rev Biochem 2004; 73:177-208.

5 Lingner J, Hughes TR, Shevchenko A, et al. Reverse transcriptase motifs in the catalytic subunit of telomerase. Science 1997; 276:561-567.
6 Lingner J, Cech TR, Hughes TR Lundblad V. Three Ever Shorter Telomere (EST) genes are dispensable for in vitro yeast telomerase activity. Proc Natl Acad Sci USA 1997; 94:11190-11195.

7 Liao XH, Zhang ML, Yang CP, Xu LX Zhou JQ. Characterization of recombinant Saccharomyces cerevisiae telomerase core enzyme purified from yeast. Biochem J 2005; 390:169176.

8 Henderson ER, Blackburn EH. An overhanging 3' terminus is a conserved feature of telomeres. Mol Cell Biol 1989; 9:345348.

9 Gao H, Cervantes RB, Mandell EK, Otero JH, Lundblad V. RPA-like proteins mediate yeast telomere function. Nat Struct Mol Biol 2007; 14:208-214.

10 Nugent CI, Hughes TR, Lue NF, Lundblad V. Cdc13p: a single-strand telomeric DNA-binding protein with a dual role in yeast telomere maintenance. Science 1996; 274:249-252.

11 Lin JJ, Zakian VA. The Saccharomyces CDC13 protein is a single-strand TG1-3 telomeric DNA-binding protein in vitro that affects telomere behavior in vivo. Proc Natl Acad Sci USA 1996; 93:13760-13765.

12 Taggart AK, Teng SC, Zakian VA. Estlp as a cell cycle-regulated activator of telomere-bound telomerase. Science 2002; 297:1023-1026.

13 Bourns BD, Alexander MK, Smith AM, Zakian VA. Sir proteins, Rif proteins, and Cdc13p bind Saccharomyces telomeres in vivo. Mol Cell Biol 1998; 18:5600-5608.

14 Mitton-Fry RM, Anderson EM, Theobald DL, Glustrom LW, Wuttke DS. Structural basis for telomeric single-stranded DNA recognition by yeast Cdc13. J Mol Biol 2004; 338:241255.

15 Mitton-Fry RM, Anderson EM, Hughes TR, Lundblad V, Wuttke DS. Conserved structure for single-stranded telomeric DNA recognition. Science 2002; 296:145-147.

16 Wang MJ, Lin YC, Pang TL, et al. Telomere-binding and Stn1p-interacting activities are required for the essential function of Saccharomyces cerevisiae Cdc13p. Nucleic Acids Res 2000; 28:4733-4741.

17 Hughes TR, Weilbaecher RG, Walterscheid M, Lundblad V. Identification of the single-strand telomeric DNA binding domain of the Saccharomyces cerevisiae Cdc13 protein. Proc Natl Acad Sci USA 2000; 97:6457-6462.

18 Lin YC, Hsu CL, Shih JW, Lin JJ. Specific binding of singlestranded telomeric DNA by Cdc13p of Saccharomyces cerevisiae. J Biol Chem 2001; 276:24588-24593.

19 Qi H, Zakian VA. The Saccharomyces telomere-binding protein Cdc13p interacts with both the catalytic subunit of DNA polymerase alpha and the telomerase-associated est 1 protein. Genes Dev 2000; 14:1777-1788.

20 Evans SK, Lundblad V. Est1 and Cdc13 as comediators of telomerase access. Science 1999; 286:117-120.

21 Grandin N, Reed SI, Charbonneau M. Stn1, a new Saccharomyces cerevisiae protein, is implicated in telomere size regulation in association with Cdc13. Genes Dev 1997; 11:512527.

22 Garvik B, Carson M, Hartwell L. Single-stranded DNA arising at telomeres in cdc13 mutants may constitute a specific signal for the RAD9 checkpoint. Mol Cell Biol 1995; 15:6128-6138. 
23 Grandin N, Damon C, Charbonneau M. Ten1 functions in telomere end protection and length regulation in association with Stn1 and Cdc13. EMBO J 2001; 20:1173-1183.

24 Puglisi A, Bianchi A, Lemmens L, Damay P, Shore D. Distinct roles for yeast Stn1 in telomere capping and telomerase inhibition. EMBO J 2008; 27:2328 - 2339

25 Petreaca RC, Chiu HC, Eckelhoefer HA, et al. Chromosome end protection plasticity revealed by Stn $1 \mathrm{p}$ and Ten $1 \mathrm{p}$ bypass of Cdc13p. Nat Cell Biol 2006; 8:748-755.

26 Petreaca RC, Chiu HC, Nugent CI. The role of Stn1p in Saccharomyces cerevisiae telomere capping can be separated from its interaction with Cdc13p. Genetics 2007; 177:14591474.

27 Martin V, Du LL, Rozenzhak S, Russell P. Protection of telomeres by a conserved Stn1-Ten1 complex. Proc Natl Acad Sci USA 2007; 104:14038-14043.

28 Grandin N, Damon C, Charbonneau M. Cdc13 cooperates with the yeast $\mathrm{Ku}$ proteins and $\mathrm{Stn} 1$ to regulate telomerase recruitment. Mol Cell Biol 2000; 20:8397-8408.

29 Chandra A, Hughes TR, Nugent CI, Lundblad V. Cdc13 both positively and negatively regulates telomere replication.
Genes Dev 2001; 15:404-414.

30 Grossi S, Puglisi A, Dmitriev PV, Lopes M, Shore D. Pol12, the B subunit of DNA polymerase alpha, functions in both telomere capping and length regulation. Genes Dev 2004; 18:992-1006.

31 Chen YB, Yang CP, Li RX, Zeng R, Zhou JQ. Deflp is involved in telomere maintenance in budding yeast. $J$ Biol Chem 2005; 280:24784-24791.

32 Zhou JQ, Tan CK, So AG, Downey KM. Purification and characterization of the catalytic subunit of human DNA polymerase delta expressed in baculovirus-infected insect cells. $J$ Biol Chem 1996; 271:29740-29745.

33 Ivessa AS, Zhou JQ, Zakian VA. The Saccharomyces Piflp DNA helicase and the highly related Rrm3p have opposite effects on replication fork progression in ribosomal DNA. Cell 2000; 100:479-489.

34 Tsukamoto Y, Taggart AK, Zakian VA. The role of the Mre11Rad50-Xrs2 complex in telomerase-mediated lengthening of Saccharomyces cerevisiae telomeres. Curr Biol 2001; 11:1328-1335. 